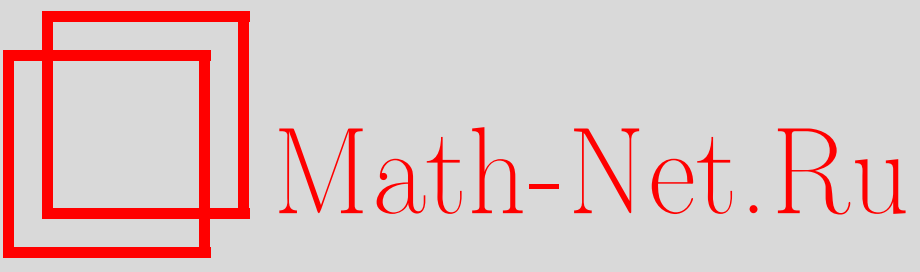

Конкурс Пьера Делиня, УМН, 2005, том 60, выпуск 3, 187-188

DOI: https://doi.org/10.4213/rm1440

Использование Общероссийского математического портала Math-Net.Ru подразумевает, что вы прочитали и согласны с пользовательским соглашением

http://www.mathnet.ru/rus/agreement

Параметры загрузки:

IP : 54.198 .67 .100

26 апреля 2023 г., 15:58:31 


\section{КОНКУРС ПЬЕРА ДЕЛИНЯ}

Преамбула. Конкурс Пьера Делиня это конкурс молодых математиков России, Украины и Белоруссии, победителям которого назначается трехлетняя стипендия. Цель конкурса - помочь молодым математикам заниматься научной работой у себя на родине.

Несколько слов о происхождении конкурса. В 2004 г. Пьеру Делиню (Institute for Advanced Study, Princeton, NJ) была присуждена премия им. Э. Бальзана. Премия была учреждена в 1956 г. Анжелой Бальзан на средства и в память ее отца Евгенио Бальзана, выдающегося журналиста и успешного предпринимателя. Эта премия присуждается Фондом Бальзана за выдающиеся заслуги в различных областях науки и общественной деятелњности. В разное время лауреатами этой премии в области математики были А. Н. Колмогоров, Э. Бомбьери, Ж.-П. Серр, А. Борель, М. Громов и др. Регламент премии им. Э. Бальзана предполагает, что половина суммы будет потрачена на проект, посвященньй поддержке молодых исследователей. Пьер Делинь решил поддержать "борющуюся российскую математику". Его заявка была принята Фондом Бальзана.

Цели конкурса. Конкурс Пьера Делиня основан для поддержки наиболее активных молодых математиков, работающих в России, на Украине и в Белоруссии. Впоследствии, по решению жюри, конкурс может быть распространен и на другие страны на территории бьвшего СССР.

Участие в конкурсе. В конкурсе может участвовать любой человек не старше 35 лет (т.е. человек, которому в год подачи заявки на участие в конкурсе исполняется не более 35 лет), имеющий степень кандидата физико-математических наук и живущий в России, на Украине или в Белоруссии.

Проведение конкурса. Участник конкурса представляет жюри исследовательский проект, рассчитанньй на три года, а также другие документы, перечисленные ниже в разделе "Подача заявки". ЖКюри конкурса отправляет проект на рецензию (при этом жюри передает рецензентам весь пакет документов, представленных на конкурс), затем обсуждает поданные заявки и отзывы рецензентов и выбирает победителей конкурса.

Каждый победитель конкурса получает диплом победителя конкурса Пьера Делиня и трехгодичную стипендию в размере 500 американских долларов в месяц (в рублевом эквиваленте). Стипендия будет выплачиваться ежеквартально в первую неделю каждого квартала. За те месяцы, большую часть которых стипендиат провел за границей (вне территории бывшего СССР), стипендия не выплачивается. Если стипендиат проводит за границей более 8 месяцев в течение года, то стипендия вьплачивается только за часть года, проведенную на территории бывшего СССР (при этом неважно, как именно это время распределяется по месяцам).

В конце каждого года стипендиат должен представлять жюри краткий отчет о достижениях прошедшего года и о планах на будущий. В нормальной ситуации жюри утверждает отчет и принимает решение о продолжении выплаты стипендии. По окончании срока выплаты стипендии стипендиат должен представить итоговый отчет.

Во всех научных работах, выполненных стипендиатом в период получения стипендии, должно содержаться указание на то, что они были осуществлены при частичной финансовой поддержке конкурса Пьера Делиня.

В настоящее время средства премии им. Э. Бальзана, полученной Пьером Делинем в 2004 г., позволяют присудить 16 стипендий: пять в 2005 г., четыре в 2006 г., четыре в 2007 г. и три в 2008 г. 
Жюри. Жюри конкурса Пьера Делиня выбрано специально для этого конкурса и не зависит от каких-либо университетов или других организаций.

В состав жюри входят два сопредседателя, два заместителя председателя, два научных секретаря и члены жюри - эксперты в различных областях математики. Жюри может быть расширено по единогласному решению членов жюри, при условии, что по крайней мере четверть членов жюри присутствует при принятии решения. Жюри нанимает специального сотрудника для решения технических вопросов.

Состав жюри: Пьер Делинь (сопредседатель), Виктор Васильев (сопредседатель), Михаил Агранович, Александр Булинский, Юрий Бурман (научный секретарь), Виктор Бухштабер, Анатолий Вершик, Эрнест Винберг, Алексей Городенцев, Юлий Ильяшенко (заместитель председателя), Вадим Калошин, Сергей Ландо, Сергей Матвеев, Сергей Натанзон, Леонид Пастур, Александр Разборов, Армен Сергеев, Искандер Тайманов, Дмитрий Трещев, Борис Фейгин (заместитель председателя), Михаил Цфасман, Александр Шень, Алберт Ширяев.

\section{Подача заявки.}

Список необходимых документов.

1. Краткое изложение заявки (Summary) - 1 страница.

2. План исследования (Research statement) - не более 5 страниц + библиографияя любого объема.

3. Краткая научная автобиография (Curriculum vitae) - 1 страница, и к ней отдельно приложить:

4. Список публикаций.

5. Список из трех потенциальных рецензентов проекта.

6. Рекомендация научного руководителя (не обязательно).

7. Оттиски научных работ.

8. Список других научных грантов участника конкурса.

Все необходимые документы следует прислать по электронному адресу pdc@mc cme.ru, a также в четьрех экземплярах по почтовому адресу: 119002, Москва, Б. Власьевский пер., 11, Конкурс Пьера Делиня.

Пояснения. План исследований (Research Statement) должен состоять из трех разделов:

1. Проведенные исследования.

2. Проект будущих исследований.

3. Преподавательский опыт и педагогические планы (не обязательно).

План должен быть адресован широкой аудитории специалистов, работающих в той же области, что и участник конкурса, и в смежных областях. В разделе "Проведенные исследования" следует приводить точные формулировки полученных результатов; в разделе "Проект будущих исследований" - также, по возможности, точные формулировки некоторых ожидаемых резултатов.

Краткое изложение заявки (Summary) должно включать в себя обзор той же информации, но без формул. Оно должно быть понятно широкой математической аудитории.

В список потенциальных рецензентов должны, как правило, входить математики, знакомые с участником конкурса лично или по работам. Предполагается, что потенциальные рецензенты готовы дать отзьв на проект.

Заявку по электронной почте желательно присылать в формате $\mathrm{T}_{\mathrm{E}} \mathrm{X}$, PostScript или PDF. По возможности не используйте другие форматы, особенно формат MS Word со сложными формулами. 